\title{
Obedience and Disobedience in Plato's Crito and the Apology: Anticipating the Democratic Turn of Civil Disobedience
}

\section{Andreas Marcou $^{1}$ (D)}

Received: 11 November 2019 / Accepted: 6 August 2020 / Published online: 21 September 2020

(c) The Author(s) 2020

\begin{abstract}
Faced with a choice between escaping without consequences and submitting to a democratic decision, Socrates chooses the latter. So immense is Socrates' duty to obey law, we are led to believe, that even the threat of death is insufficient to abrogate it. Crito proposes several arguments purporting to ground Socrates' strong duty to obey, with the appeal to the Athenian system's democratic credentials carrying most of the normative weight. A careful reading of the dialogue, in conjunction with the 'Apology', reveals, however, a more complex picture. If Crito sets the conditions that render a regime legitimate, and therefore warranting of obedience, the Apology reveals a legal system's shortcomings that justify disobedience. This article substantiates this position by delineating circumstances that can justify resistance. Contemporary forms of political resistance can also rely on similar conditions. Plato's texts anticipate the current democratic turn of civil disobedience.
\end{abstract}

Keywords Crito $\cdot$ Apology $\cdot$ Duty to obey $\cdot$ Democratic legitimacy $\cdot$ Persuade or obey $\cdot$ Civil disobedience

\section{Introduction}

Unjustly charged with corrupting Athenian youth, introducing new deities, and rejecting Athens's ancestral gods, Socrates is convicted by a jury of his peers and sentenced to death (Apology 24b). ${ }^{1}$ His disciple, Crito, visits him in jail. Plato's Crito portrays his last-ditch effort to persuade Socrates to escape execution. The dialogue

\footnotetext{
1 All references to Platonic texts are to John Cooper's edition (Cooper 1997). There is considerable ambiguity whether the Platonic Socrates is an accurate depiction of the real Socrates. I shall not discuss this matter. Following broad academic consensus, I simply assume that, at least in early dialogues such as Crito, we get a fairly accurate portrayal of Socrates. See Vlastos (1991: 45-48). Cf. Kahn (1996).
}

Andreas Marcou

a.marcou@qmul.ac.uk

1 Department of Law, Queen Mary University of London, London, UK 
begins with the eponymous character lamenting the consequences Socrates' death will have for those closest to him. His friends may face scorn from Athenians for failing to assist a friend wrongly sentenced to die. Socrates' choice to accept death would therefore tarnish their reputation (Crito 44c). In refusing to leave, Socrates also betrays his parental duties. His family will suffer because of his death (Crito 45d). Crito next assuages Socrates' possible fears about his escape. Informers can be bought off easily thus ensuring a successful escape (Crito $44 \mathrm{e})$, while several places, like Thessaly, will welcome Socrates and let him spend the rest of his days freely, presumably philosophising (Crito 45c. Cf. Crito 53b, Apology 37c, 38a). Crito also criticises 'the handling of the trial itself' (Crito 45e), alluding to an improper procedure. But no evidence indicates any procedural impropriety. Indeed, as I suggest later, the procedure's formal legitimacy remains largely unchallenged. Socrates must obey, we shall see, precisely because the appropriate democratic procedures were observed.

Socrates swiftly shrugs off Crito's claims (Crito 48c). They are largely personal appeals, failing to invoke a principled (as opposed to self-interested) reason why Socrates' escape is warranted. Academic scholarship often dismisses Crito as either unwilling to seriously challenge Socratic arguments or incapable of doing so (see e.g., Dagger and Lefkowitz 2014; Young 1974). And although his unpersuasive appeals to personal detriment, money, and family justify the characterisation we must not simply disregard his claims. Trivial as they may seem, Crito's arguments remain relevant. In assuring an unobstructed escape, Crito removes self-interested reasons for obedience. Socrates, Crito guarantees, can breach the law with impunity; bribery of prison guards, for example, ensures he can escape without consequences (e.g., Crito 46a. Also Gowder 2015). In response, Socrates discusses several arguments that explain why impunity is irrelevant to the possibility of disobedience. The philosopher is interested in principled reasons for his action (Crito 46b). He therefore proposes and defends claims that plausibly ground a general duty to obey. ${ }^{2}$ So strong and multi-faceted are the arguments for obedience that the dialogue has been traditionally considered the archetypical treatise on absolute obedience to law with Socrates emerging as the quintessential apologist of democratic authority (See e.g., Taylor 1927: 168; Zinn 1991: 909-910; Delmas 2017: 195-196).

This article aims to subvert that interpretation. I begin by surveying Socrates' arguments for obedience, in Sect. 2. Considerations such as the destructive effect of disobedience on the legal system or Socrates' agreement with the polis clearly support Socrates' belief that he is bound by the jury's decision. But in the end, it is democratic citizenship, which I investigate in Sect. 3, that emerges as the primary ground upon which a claim for general obedience is plausible. Socrates is embedded in a democratic system the sheer existence of which warrants, prima facie, Socrates' obedience, irrespective of the specific justice of

\footnotetext{
${ }^{2}$ Contemporary discussions on political obligation insist that such duty is general, moral, content-independent, and prima facie. See e.g., Simmons 1979; Smith 1973. The duty exists in addition to any moral duties to obey created by virtue of a law's substantive moral value. All references to a duty to obey law, unless otherwise stated, will be to this general, content-independent commitment.
} 
this or that pronouncement. Athenians, including Socrates, incur a strong duty to obey to the extent that the legal system remains democratic. My analysis portrays democratic citizenship and civic engagement as the legitimating criteria of a legal system.

With these criteria in mind, we can proceed to investigate the possibilities of disobedience, a task I undertake in Sect. 4. When read together, Crito and the Apology, reveal a complex picture of citizens' appropriate attitude to law, shedding light on limits to obedience. I shall argue that classical liberal interpretations of civil disobedience (e.g., Rawls 1999) cannot fully accommodate all the circumstances of justified disobedience found in Plato's texts. But such examples can be more easily reconciled with democratic theories of civil disobedience. Theorists from Arendt (1972) to Habermas (1985) and more recently to Markovits (2005) have contended that disobedience can take place even within broadly democratic regimes for procedural rather than purely substantive reasons. Plato's discussion on circumstances of morally permissible disobedience, I shall argue, anticipates that approach.

\section{Grounds of Obedience}

To counter Crito's appeals, Socrates envisions the personified Laws of Athens (nomoi kai to koinon tis poleos) confronting him and challenging his possible decision to leave. ${ }^{3}$ It should be borne in mind, however, that in that imagined encounter Socrates serves as a proxy for every Athenian citizen. The Laws' speech mostly consists of arguments couched in general terms with only occasional references to Socrates' own distinctive (and atypical) position within the Athenian system (see Crito 52a-b, on claims directly aimed at Socrates' particular position). That is no accident. Again, what is at stake here are principled reasons for (or against) obedience (Crito 46b, 48c-d). Far from a targeted claim at Socrates' obedience, the Laws' purport to explain why all democratic citizens confronted with an unjust political outcome have a prima facie duty to abide by it. The abstract scope of the speech also enables us to extrapolate from it criteria for legitimacy, which can then be used to explain citizens' commitments to law.

The Laws' exhortation for obedience begins with a basic concern about disobedience:

Do you not by this action you are attempting intend to destroy us, the laws, and indeed the whole city, as far as you are concerned? Or do you think it possible for a city not to be destroyed if the verdicts of its courts have no force but are nullified and set at naught by private individuals? (Crito 50b)

\footnotetext{
${ }^{3}$ See Woozley (1979) on the Laws' speech as reflective of Socratic views. Cf. Young (1974), on the claim that the Laws discuss claims not necessarily adopted by Socrates himself but arguments that can successfully persuade Crito and others with his limited intellectual capacity. See also Weiss (1997), Rosano (2000).
} 
Socrates must submit to the jury's decision, lest he endanger the entire legal system. ${ }^{4}$ But is it possible for an isolated act of disobedience to destroy a legal system? Some individual disobedience may indeed prove exceptionally damaging, notably where overall security is jeopardised (e.g., Alcibiades' disobedience during the Peloponnesian War) (Kirkpatrick 2015: 364; Finnis 2011: 361). It generally seems difficult, however, for solitary law-breaking to bring down a legal structure-even a small society such as a Greek polis.

For Plato, however, disobedience menaces the legal system insofar as it reveals a general attitude of disrespect to law's authority. Those who destroy laws 'corrupt the youth and the ignorant', flouting the system's authority and setting bad examples, thus inciting further lawbreaking (Crito 53c) ${ }^{5}$ Such adverse consequences render obedience urgent. A legal system loses effectiveness if citizens deem their duty to obey weak and easily offset; citizens' respect for law erodes, breeding unlawfulness. The Laws' denunciation of disobedience stands as a warning. When citizens fail to perceive decisions taken following otherwise legitimate procedures as creating strong duties of obedience, law becomes undermined. A similar warning pertains to contemporary societies: if disobedience signifies a reduced sense of law-abidingness, the legal system's authority and stability is threatened. ${ }^{6}$

The 'destructive effect' thesis is seemingly particularly persuasive for Athens, where citizens' relationship with law is intimate. Nomos includes not only formally enacted law, but also customs and traditions, assuming a greater degree of social cohesion (Heinze 2016: 117; 2018: 121). ${ }^{7}$ Disobedience corrupts nomos at the expense of communal spirit, eroding bonds that hold citizens together. ${ }^{8}$ The entire

\footnotetext{
${ }^{4}$ See Kraut (1984: 48-50), on the argument for destruction read together with the filial gratitude and benefits argument.

5 See, in a similar spirit, Aristotle's concern that 'illegality creeps in unnoticed' and destroys the constitution, warranting thus robust response to even small violations, Politics, 5.8.1307b32-33. References to Aristotle's Politics are to C.D.C. Reeves's edition (Aristotle 1998).

6 See also Hart (1982: 160-161), on how some moral commitment to the legal system is necessary for its stability (though this is only a contingent truth about the connection between law and morality). See also Douzinas (2013: 64-65), on lawbreaking as an indication of national corruption.

7 By contrast, decrees (psephismata) refer to ad hoc legal enactments rather than general pronouncements, Nicomachean Ethics, 5.10. 1137b13-35. References to Aristotle's Nicomachean Ethics are to Terence Irwin's edition (Aristotle 1999).

8 Citizenship in Athens was restricted to only a fraction of the total population. The vast majority of residents in Athens was excluded from formal citizenship and thus deprived the opportunity of self-government. Women, though citizens, were denied several political rights (e.g., speaking in public, participating in law-making). Slaves and non-Athenians were not citizens at all; although non-Athenians residing in Athens (metics) for long could accumulate significant wealth and thus exert some socio-political power (See e.g., Cephalus in Republic 1). Decision-making procedures were only open for citizen-born male heads of households. In this sense, Athenian democracy resembles an oligarchy: the few male citizens exercise political power, often at the expense of other non-citizens (see Heinze 2018: 119). Such restrictive citizenship criteria threaten to render any discussion of ancient democracies outdated. This need not be the case. Several modern scholars, including women, have generally considered classical citizenship criteria (chiefly inspired by Aristotle) adaptable for contemporary, often politically progressive, applications (Arendt 1998; Marcia 2002; Nussbaum 1990). Throughout this article, in discussing classical models of citizenship, I focus on citizenship's content rather than its boundaries. The question of what it means to be a citizen is more pertinent for my purposes than questions of who gets to be a citizen (incidentally, the latter question remains within the regulatory jurisdiction of modern states).
} 
normative structure of a polis is threatened through citizen disrespect. Such bonds are arguably lacking in contemporary societies, which embody a lower degree of social cohesion. Yet the general point remains. Every legal system can claim reasons to be alarmed by citizens' propensity to lawbreaking.

At any rate, consequential arguments can hardly offer conclusive reasons either for or against disobedience. Although societies ought to be concerned with legal violations, it is implausible to maintain that even innocuous, harmless lawbreaking undermines a legal order (see e.g., Raz 1979: 238-241. Cf. Finnis 2011: 361). And if not all disobedience is equally corrosive to the legal system, then a general duty to obey cannot be based solely on the 'destructive effect' thesis. Although that thesis buttresses Socrates' belief that breaking the law is unjust, it cannot establish, on its own, principled reasons against disobedience.

The personified Laws then refer to citizens' agreement to obey their polis's laws. They remind Socrates of his commitment: 'the agreement between us, Socrates,... [was] to respect the judgments ... [of] the city' (Crito 50c). ${ }^{9}$ Portraying tacit consent to a fundamental pact as creating an obligation to obey, the Laws stake a strong claim to citizens' obedience. Assuming it is morally right to honour one's agreement, citizens are bound to obey democratic laws. A just agreement must be fulfilled. 'When one has come to an agreement that is just with someone', Socrates asks Crito, 'should one fulfil it or cheat on it?' (Crito 49e) The proviso of justice raises further questions (See e.g., Kraut 1984: 29-32). ${ }^{10}$ Does Socrates mean that the agreement is binding only if its content is just? Or is it a question of the justice of the conditions under which agreement was reached, that is without duress or compulsion? The latter is more plausible considering later emphasis on the agreement's circumstances. Socrates, the Laws explain, agreed 'without compulsion or deceit' (Crito 52d-e). As long as the agreement is procedurally fair, citizens incur an obligation to obey its provisions. An otherwise legitimate contract cannot be breached ordinarily simply on grounds of detriment. ${ }^{11}$ By analogy, Socrates cannot breach his pact with the state simply because he is convicted; the procedures are legitimate and the agreement ought to be upheld.

Athenian citizens, including Socrates, must discharge their contractual obligation to obey even if they are, on occasion, at a disadvantage. They have enjoyed numerous benefits from the polis because of their agreement:

Did we not, first, bring you to birth, and was it not through us that your father married your mother and beget you?.... Or [do you find anything to criticise] in those of us concerned with the nurture of babies and the education that you too received? Were those assigned to that subject not right to instruct your father to educate you in the arts and in physical culture? (Crito 50d-e)

\footnotetext{
${ }^{9}$ For attempts to establish political obligations on consent see Locke (1980: 180); Plamenatz (1968). Cf. Pitkin (1965). Virtually all varieties of consent are subject to severe criticism, e.g. Smith (1973: 960964); Simmons (1979).

${ }^{10}$ Rawls's account of political obligations grounded on fair play also includes a proviso for justice (Rawls 1964: 9). For Rawls, principles of fairness only operate when the relevant joint enterprise is fundamentally just. But see Simmons 1979: 109-114.

11 But see unconscionable contracts.
} 
The conferred benefits, such as education, presuppose a tacit, reciprocal agreement. Citizens receive them so long as they obey (on law's facilitative and educative function see e.g., Apology 24e, Politics, 1266b30, 1287a15-30, 1310a12-23, 7.17. See also Hart 2012: 26-49). Having enjoyed these benefits, they must, in fairness, submit to law. Principles of fairness are often used to ground citizens' duties of obedience. Within cooperative enterprises that administer benefits, participants who enjoy benefits as a result of other members' obedience owe it to them to obey the rules of the system (Hart 1955: 185; Rawls 1964: 9-10. ${ }^{12}$ For criticism see (Simmons 1979: 131-132, 139; Smith 1973: 955-959). Should Socrates disobey, he would be acting unfairly towards his fellow citizens who support the regime through obeying its laws. Only such cooperation makes it possible for Athenians to enjoy the scheme's benefits. Even if Socrates' disobedience would not directly (or at all) impact other citizens' receipt of those benefits, it would remain unfair for him to breach the rules of the cooperative enterprise. ${ }^{13}$

The polis, as the benefit-provider, assumes a parental position that seemingly admits no recalcitrance (Crito 50e-51a). Some theorists, inspired by this analogy between the state and one's parents, defend a commitment to law grounded on filial gratitude (see e.g., Walker 1989: 364). But the Laws move beyond the limits of gratitude, stressing the entrenched power inequality between the polis as a decisionmaker and its citizens as decision-receivers. Just as citizens are 'not on an equal footing with [their] father as regards the right', they are also subjects to law's authority (Crito 51a). In fact, the polis ought to be more honoured, more revered, and more respected than one's parents or ancestors (Crito 51a). Citizens have no choice but to obey. Even if the state attacks its own citizens, or 'undertake[s] to destroy [them]', retaliation and resistance remain unfathomable (Crito 51a). Interestingly, those faced with the polis's overbearing authority resemble slaves forced to live under the rule of a master. ${ }^{14}$ Like slaves enduring whatever their masters' command, citizens must always submit to the city's pronouncements.

It is only with the first reference to democratic citizenship and the opportunities citizens enjoy of persuading others about prospective laws that this dogmatic position is softened (Crito 51b-c). Far from depriving citizens' freedom, the legal system actually facilitates numerous choices for Athenians. Every fully-fledged citizen has the 'opportunity, once arrived at voting age and having observed the affairs of the city and us the laws....[to] take his possessions and go wherever he pleases' (Crito 51c-e). Vaunting the freedom afforded to citizens wishing to emigrate, the Laws depict participation in Athenian affairs as a matter of free choice. To be sure, it is contentious whether the choice to leave one's state is ever, or indeed was for Athenians, tenable, given the extraordinary costs associated with severing deep family ties and friendships normally attached to the exit option (See e.g., Kirkpatrick 2015. Also Hume 1994: 193; Simmons 1979, Ch. 3-4; Dworkin 1998: 1992).

\footnotetext{
12 In his Theory of Justice, Rawls sees the principle of fairness as playing an ancillary role, with the principle of natural duties being the primary ground of political obligation (Rawls 1999: 310).

13 As I argue in Sect. 3, the strongest statement of the fairness argument takes into consideration the democratic character of the political enterprise.

14 '[You were not on an equal footing] with your master, if you had one' (Crito 50e, emphasis added).
} 
But that passage also highlights Socrates' notable unwillingness to leave Athens. Not only did he never venture away from Athens, except to undertake military service, but he also refused to request the exile penalty during his trial (Crito 52c-53a. Apology, 37e; Crito 51c-e). Far from grudgingly obeying the law, Socrates decisively and emphatically enjoyed living under Athens's democratic institutions (Crito $52 \mathrm{~b}-\mathrm{c}$ ). Socrates' commitment to law, even in the face of the jury's flawed decision, chiefly stems from his loyalty to democracy. Democratic citizenship endows Athenians with opportunities to participate in decision-making processes and shape political outcomes. Such opportunities legitimise the Athenian system and generate in Socrates (and other Athenians) general duties of obedience.

\section{Democratic Citizenship}

\section{1 'Persuade or Obey'}

The preceding considerations, such as the citizens' agreement with the polis, are by no means inconsequential to Socrates' decision to abide by the jury's decision. But they cannot provide, on their own, firm grounds for establishing a general duty for obedience. It is rather the democratic character of the Athenian legal system that establishes Socrates' obedience. Democratic citizenship, the Laws remark, is associated with the citizens' opportunity to 'either persuade [the polis] or obey its orders, and endure in silence whatever it instructs you to endure' (Crito 51b). Obedience is expected, and indeed justified, because (or to the extent that) citizens have been allowed opportunities to persuade their fellow citizens 'as to the nature of justice' and therefore the appropriate content of laws (Crito 51c).

The formula 'persuade or obey' appears multiple times in the Laws' speech and emerges as the salient condition upon which a claim to general obedience is grounded (first at Crito 51b and then again at 51c, and 52a). Persuasion in this context is a communicative, deeply political activity. Although it may initially seem a private attempt to change another person's mind, it is emphatically a mode of public address. Socrates has agreed to 'be a citizen under us' (Crito 52c), the Laws exclaim. And being a citizen is nothing but to engage in political activity (politeuesthai) (Crito 52c). Persuasion presupposes opportunities to participate in politics. Engaging fellow citizens in an effort to persuade them becomes the hallmark of democratic citizenship. This is a richer interpretation of democratic citizenship beyond commonplace understandings of citizenship in terms of sheer legal status (Heinze 2016: 108).

Open access to political processes, I argue, legitimises Athenian democracy. The Athenian system empowers citizens to persuade others, both in legislative and judicial procedures. As long as it secures ample opportunities for civic engagement, Athens remains a legitimate regime capable of staking a claim to its citizens' general obedience even when it produces substantively flawed outcomes. Absent opportunities for persuasion, the formula is inapplicable. In that case, there is no justification for claiming citizens' general obedience. If a citizen's 
duty to obey depends on the opportunities for civic engagement available, it follows that should such opportunities diminish, the duty weakens.

Within a regime facilitating citizen engagement, dismissing democratic laws would be unfair. The fairness argument outlined earlier ${ }^{15}$ reinforces the claim from democratic citizenship considered here. Within a democratic cooperative enterprise, such as the Athenian democracy, distribution of benefits (and burdens) is ultimately regulated not by a central authority, but by collective decision-making. ${ }^{16}$ The democratic system's legal processes, and the decisions it reaches, are shaped by citizens. Socrates owes his obedience to his fellow citizens who play by the rules of the game, submitting themselves to the authority of collectively decided laws. ${ }^{17}$ Athenian citizens, as participants to the democratic enterprise, would be violating their duties in fairness if they refused to obey collectively decided laws because they judged them to be somewhat unjust.

Precisely because it secures inclusive and meaningful democratic processes, Athens, the Laws are quick to assure us, never 'issues savage commands' (Crito 52a). Far from impositions, laws are the product of processes citizens control; the laws embody, then, the collective will of Athenians (see e.g., Ober 2002: 187). Even when a process's outcome is antithetical to one's interests or convictions, obedience is warranted. Citizen engagement with politics legitimises the savage; what would otherwise be a crude command, the instrument of sheer political power, becomes law, worthy of obedience and respect (see Heinze 2018: 123). Athenian citizens, therefore, incur strong duties of obedience. Yet, as I shall show in Sect. 4, it remains possible for a broadly legitimate regime, such as the Athenian democracy, to issue commands with 'savage' content. Such outcomes raise dilemmas for committed citizens.

'Persuade or obey' relates to political engagement, but of what kind? Socrates abstains from formal political activities except when the law specifically commands them of him (Apology 31d-32b). He is nevertheless an active participant of Athenian democracy, spending his days in the agora-the public space where citizens routinely discuss social, ethical, religious, or political issues (Apology 31b). Plato's dialogues testify to Socrates' willingness to converse with anyone about topics of political and ethical importance (see e.g. Euthyphro, Charmides, Laches). For Ancient Athenians, politics encompasses the entirety of social interactions, including the proper conduct of citizens, their ethical and civic education, and so forth (e.g., Nicomachean Ethics 10.9). The agora constitutes a forum of public discourse that forms an inextricable component of democracy (See e.g., Heinze 2018; Habermas 1996). For Socrates, to speak with fellow citizens about public issues is as politically relevant as, or perhaps even superior to, participation in any formal political institution

\footnotetext{
$\overline{15}$ Text accompanying notes $12-13$.

16 Hart's formulation of the fairness argument remains silent on the requirement for democracy. By contrast, according to Simmons, Rawls's insistence on a voluntary cooperative enterprise (Rawls 1964: 9, emphasis added), his requirement that benefits and burdens are distributed justly, and his overall support for constitutional democracies suggest that the fair play account assumes a generally democratic system (Simmons 1979: 136-137). Although I do not think that the fairness argument strictly requires a democratic society, it fits with the claim of democratic citizenship proposed here.

17 On how the duties of fairness are owed to one's fellow citizens see Rawls 1964: 10.
} 
(compare Apology 17c-d with 31d-32b). Socrates refrains from formal law-making processes but features prominently in Athenian public life; so absolutely dedicated is he to public matters that he has, throughout his life, neglected his private affairs, a choice which has left him destitute (Apology, 31-e, 36b). In this sense, his actions (and, importantly, the freedom he has to engage in them) betoken his civic engagement. Socrates' extra-institutional conduct may be the most effective way for him to participate in democratic government by seeking to persuade his fellow citizens (Apology 30e-31a, 31b, 36c). His bleak view of institutional politics articulated in the Apology corroborates this position. ${ }^{18}$

The 'persuade or obey' doctrine extends to judicial proceedings as well. In contemporary states, judicial processes are stripped of democratic elements, with the limited exception of citizen juries. Yet in Athens, judicial processes maintain a thoroughly democratic character. ${ }^{19}$ Citizens accused of wrongdoing address an assembly of their fellow citizens, whom they attempt to persuade of their innocence. Socrates is in a similar position - if he persuades the jury, he will be acquitted (Apology 35c, $38 \mathrm{c}) .{ }^{20}$ The trial's democratic character, it being a process where persuasion can occur, means that Socrates is bound by the outcome. Should Socrates ignore the jury's judgment and escape, far from simply breaching a command, his disobedience would show contempt for democratic processes (Crito 51e '[the one who disobeys] neither obeys us nor, if we do something wrong, does he try to persuade us to do better'). Fleeing Athens would illustrate an attempt to substitute a legitimate democratic decision with his individual judgment.

Had Socrates been denied a proper trial, and thus an opportunity to persuade, the Athenian legal system's legitimacy would come under question. We can only speculate how Socrates' duty to obey would change in that case. The Laws, apparently unconcerned with the conviction's substantive injustice, admonish Socrates to direct his grievances against 'men, not the laws' (Crito 54c). Athenian laws establish fair judicial processes, but the citizens comprising the jury may reach wrong decisions. Even when procedures are correctly set out, the content of democratic decisions ultimately depends on citizens' opinions and actions. It is by no means a novel idea that just processes may in fact produce substantive injustice sometimes (see e.g., Nicomachean Ethics, 5.10). Legitimate procedures nevertheless beget duties of obedience irrespective of their occasional substantive failures. Socrates' conviction results not from an unjust process but from his fellow citizens' judgment (See e.g., Ober 2002: 183; Todd and Millet 1990).

This flattering depiction of democratic Athens as broadly legitimate and just seems surprising in light of Plato's denunciation of democracy as arbitrary and inherently flawed. ${ }^{21}$ Democracy inevitably degenerates, Plato fears, into lawlessness;

\footnotetext{
${ }_{18}$ It is impossible for someone to participate in formal politics and pursue justice, see Apology 32a, 32e, 36 c ('too honest to survive if I occupied myself with those things').

19 Athenian juries consisted of a few hundred citizens (two hundred and one, five hundred and one, and so forth). They were therefore much smaller than legislative assemblies, such as the Ecclesia, which consisted of a few thousand citizens (typically about 6000).

20 On the Athenian legal system in general, see MacDowell (1978: 247-254).

21 See e.g., Republic 6.492b-c (on democracy's corruption), Republic 6.496c-d (on the insanity of the masses), Republic 8.561d (on democratic citizens' lack of order), Republic 6 (democracy's shortcomings, e.g., 499d-500b). For related criticisms see Apology 29e-30b (on critique of market-driven individualism and pursuit of luxury), Apology 36b (on democracy's factions).
} 
it regresses into 'ochlocracy' or mob rule (e.g., Republic 8, 563d-e). Contrary to the Laws' defence of Athenian democracy, Plato sees democratic actions as irrational and savage. In the Republic, he scraps democratic rule as inherently unstable and incapable of producing justice consistently (Republic 8, 555b-564e). ${ }^{22}$ These two contrasting dispositions are mirrored even within the short space of Crito. The Laws' vigorous endorsement of democratic legitimacy contrasts with the haphazard nature of a democratic people Socrates lambasts at an earlier point in his exchange with Crito (Crito 44c-d). Addressing this inconsistency, Eric Heinze (2018: 119-120) suggests that Plato's rejection of democracy in the Republic rests on democracy's failure to attain the standards of legitimacy he defends within his ideal state. By contrast, his aim in Crito involves evaluating Athens on its own criteria of legitimacy.

\section{2 'Persuade or Obey' in Contemporary Politics}

I have thus far attributed to Crito a model of democratic citizenship constructed around the idea of popular government. Several theories take some form of political participation in popular government to constitute a condition of political legitimacy and advocate active citizenship. Civic republican theories, in particular, frequently draw inspiration from classical models of democracy (see e.g., Arendt 1998). Also Pettit (2012). ${ }^{23}$ But models of legitimacy advocated by contemporary theorists differ from that defended by the Laws. The latter depends on self-government exercised within a direct democracy, a stipulation mostly lacking in current theories.

Crito's choice between persuasion and obedience presupposes a sharp distinction between the stages before and after a law is adopted by a direct democracy. Persuasion is restricted to pre-decision-making processes (Brickhouse and Smith 2004: 222; Kraut 1984: 56, 63-64). Up to and including the point at which a proposed action is debated, fully-fledged Athenian citizens may participate in the decisionmaking process and try to persuade. Once decisions are made, all citizens, irrespective of their personal judgments, interests, or preferences must obey. Although dissent is surely allowed-citizens can debate about the law and even attempt to change it - they must still obey (Brickhouse and Smith 2004: 221). In this context, persuasion is meaningful: it is open for any citizen and can have appreciable impact on political outcomes. But within modern systems, the choice between persuasion and obedience seems contrived. Legislatures vote on many and complex issues, with few constituents likely to agree with their representatives on every vote. The size of modern states means that most citizens can scarcely be heard. The choice between persuasion and obedience nowadays only applies, if at all, to actual representatives.

A state's institutions largely depend on socio-historical conditions. Direct democracy might have been a suitable instrument for securing broad citizen participation in the milieu of a small ancient polis. Yet current societies with vast populations cannot easily manage direct democracy as a means of securing fair and equal

\footnotetext{
22 Plato's rejection of democracy resonates throughout history. Rancière (2006: 8-9) traces to Plato a hatred for democracy that infects all subsequent philosophers.

${ }^{23}$ Contemporary republicans such as Pettit dissociate their theories from classical ideas of citizenship because of their supposedly irresistible association with positive freedom. But see Brown (2001).
} 
political participation for citizens. Direct democracy is not only practically untenable, especially considering the highly technical character of contemporary legislation, but is also susceptible to majoritarian abuses that threaten vulnerable minority groups (see e.g., Pettit 2012: 188-194; Pettit 1997, ch. 6. Also Politics, 4.1292a4-30 (on the tyrannical and oppressive nature of unbridled direct political participation)). How are the criteria of legitimacy found in Crito, then, relevant for contemporary societies $?^{24}$ If civic participation and democratic citizenship are intelligible only in the extraordinary socio-political context of ancient Athens, then Crito offers little guidance for modern states.

We cannot apply Crito willy-nilly to modern, vastly and densely populated societies (see e.g., Herrera 1995: 49). Nevertheless, Crito's criteria for legitimacy are adaptable for current regimes. For example, it is plausible to maintain that allowing opportunities for citizens to engage in politics and try to persuade others enhances a regime's legitimacy. Yet references to persuasion cannot simply entail conduct taking place at the pre-decision-making stage. We must extend the formula to allow persuasion to occur in post-decision-making contexts, targeting existing not merely prospective laws. One way is to see mechanisms designed to contest executive and legislative decisions as post hoc attempts at persuasion of fellow citizens and law-makers. Challenging a political decision in court, for example, can be construed as an attempt to persuade others about the unfairness or impropriety of a legitimate decision (or even scrutinise its very legitimacy). As long as contestation remains within legal limits, seeing dissent as attempted persuasion raises few concerns. Even if citizens choose to contest, they typically obey law while their challenge is addressed.

But if formal political processes, including contestation, are too narrow arenas for persuasion to take place, then we can plausibly think of persuasion occurring beyond those forums. For A.D. Woozley (1979: 30-37), we must admit civil disobedience as a means to persuade fellow citizens about a law's injustice. To be sure, Crito leaves no room for this reading (Woozley 1979: 37; Herrera 1995: 49). Nor is there reason to assume that had Socrates escaped, his disobedience could have been reconstructed as attempted persuasion. It would be difficult to defend such a claim, considering the absence of an audience to which Socrates would direct his disobedience.

Civil disobedience emerges, nevertheless, as an appropriate way to engage in political activity and therefore persuade others within contemporary broadly democratic regimes. For present purposes, I adopt a broad definition of civil disobedience as non-violent lawbreaking committed with the intention of communicating a political message. Civil disobedience can be direct or indirect: in the first case, dissidents directly disobey the (unjust) law they protest and wish changed, whereas in the second, dissidents breach a law that is perfectly just as a means of challenging another flawed law. Following academic practice, I take both cases of direct and indirect disobedience to involve similar considerations (in both cases dissidents protest some

\footnotetext{
${ }^{24}$ Several theorists cast doubt on the extent to which one can use ideas developed in such radically different contexts. See e.g., Waldron (2005: 35); MacIntyre (1994: 302-303). But see Saffron and Urbinati (2013: 445); Rancière (2006: 37) (on how problems ancient societies faced (e.g. majoritarianism, political abuse, citizen apathy) still trouble us today).
} 
unjust law, they wish to attract attention to its injustice, they pursue its change and so forth). The central feature of the model of civil disobedience I use here is communicativeness, which embodies the political character of civil disobedience (Rawls 1999: 321; Arendt 1977: 74-76; Brownlee 2012). Addressing their fellow citizens, civil disobedients fulfil a persuasive role. Indeed, for paradigmatic civil disobedient Martin Luther King, this protest is the 'ultimate form of persuasion' (King 1986: 484). Indirect democracies, which stress alternative means of citizen engagement beyond direct participation in political institutions, can and ought to recognise the civic potential of suitably constrained lawbreaking in civil disobedience, and facilitate the protest as a tool for political persuasion. A strict reading of the "persuade or obey' formula probably excludes civil disobedience as an option, given that failures to persuade (assuming adequate opportunities to attempt persuasion) must always be followed by adherence to law. But adapting the criterion of persuasion for contemporary contexts inspires an interpretation of civil disobedience as a legitimate form of political activity, a way in which citizens seek to persuade others that the legal system is, in some respects, flawed.

\section{Grounds of Disobedience}

Socrates is widely considered a great dissident, largely because of his renowned questioning of conventional beliefs. It is to Socrates' 'gadfly' (oistros) role (Apology 30e) that King (1991: 71) likens his own actions. In contrast to King who deliberately broke the law, however, Socrates opts to obey. If anything, Crito seemingly dispels any suggestion that Socrates is willing to break the law. It may appear difficult to see why Socrates is even associated with civil disobedience, especially in light of the term's modern connotations (Kraut 1984: 76). ${ }^{25}$ For C.D. Herrera (1995: 43, 46), the dialogue offers no evidence to suggest that Crito contemplates Socrates breaching the law as a means of attracting his fellow citizens' attention over his undeserved conviction. Nor is there evidence to suggest that Crito wants to change Athenian laws he deems particularly immoral or otherwise objectionable-the proper subject matter of civil disobedience (but see Socrates' distaste for the jury's decision, Apology 39c-e). But when read together, Crito and the Apology help us to identify circumstances under which disobedience becomes justified.

The choice between persuasion and obedience seems at first blush to leave little room for justified disobedience, making Crito appear authoritarian (see e.g., Heinze 2018: 121-123; Kraut 1984: 5). Consider an Athenian citizen objecting to a proposed law. The first step is to attempt to persuade his fellow citizens. Participating in the relevant legislative assemblies, he may speak freely. His plea will either be accepted or rejected. If it is accepted, the citizen will presumably accept the

\footnotetext{
25 Henry David Thoreau is generally credited with coining the term in his 1849 essay originally entitled 'Resistance to Civil Government', reprinted as 'Civil Disobedience' in Hugo Bedau's (1991) seminal collection of essays on civil disobedience, 'Civil Disobedience in Focus'. Crito also appears, by way of introduction, in the same collection.
} 
resulting law. If the plea fails, he must nonetheless obey the result. Some suggest, then, that Crito preaches blind obedience to law (See e.g. Taylor 1927: 168; Zinn 1991: 909-910). ${ }^{26}$ Scholars adopting such interpretations of Crito maintain that it is irreconcilable to the Apology. The former advocates a model of strict obedience to law while the latter reveals Socrates' willingness to disobey (Howenstein 2009: 67-73; Olsen 1984). The paradox resolves, I argue, once we move beyond the conventional understanding of Crito as supporting ultimate deference to legal authority. I shall show that the duty Socrates perceives as binding him to Athenian law is overridable. The Apology complements Crito by suggesting circumstances under which citizens may derogate from their general duty to obey. If some disobedience is deemed justified, then it is incorrect to read Socrates' commitment to the law as absolute (Kraut 1984: 11). The next section investigates the examples of justified disobedience found in the Apology. I shall then argue that classical liberal accounts of civil disobedience cannot fully accommodate as justified all cases of disobedience envisaged by Plato. By contrast, democratic theories of civil disobedience, which view disobedience as a justified response to systemic, democratic deficits, better accommodate all examples identified in Sect. 4.1.

\subsection{The Examples of the Apology}

In the Apology, Socrates defends himself against the charge of impiety brought by his accusers. Addressing a jury, he offers valuable information relating to his attitude towards law. Socrates recalls having promptly disobeyed an unjust command, namely an order issued by the oligarchic regime of the Thirty Tyrants, imposed on Athens after her defeat in the Peloponnesian War. The Tyrants summoned Socrates and asked him to bring in Leon of Salamis, an innocent third party, to be executed (Apology 32c). Recounting the events, Socrates insists that his disobedience stemmed from a principled unwillingness to commit injustice (Apology 32d). Confronted with a sufficiently unjust command, it appears, one is unbound by the duty to obey, to the extent of that injustice.

One may surely question whether the command of the Thirty Tyrants successfully creates any duties of obedience, considering the regime's illegitimacy (see e.g., Kraut 1984: 18-21). The exclusion of the bulk of the Athenian population from self-government, and the impossibility of persuasion, renders the Tyranny illegitimate. As such, the regime creates no duty to obey. Absent such duty, one might argue, Socrates simply makes a decision based on his own judgment about justice. But this is not how Socrates justifies his action. He does not deride the Tyranny as illegitimate (cf. Woozley 1979: 54). Nothing indicates that Socrates' reason for

\footnotetext{
${ }_{26}$ Brickhouse and Smith (2004: 219) emphasise elements of the agreement between Socrates and the Laws that indicate that agreement is consistent with only provisional obedience. They argue that the 'obey or persuade' formula, an invitation to citizens to change the content of law, is part of the agreement. Therefore, citizens are given the chance to change the content of their duties of obedience. A requirement of absolute obedience, on this reading, can only be found in despotic, savage, impositions of directives on citizens.
} 
disobedience signalled resistance to the Tyranny's authority. His 'whole concern', he announces before the jury, 'is not to do anything unjust or impious' (Apology 32d). The incident reveals Socrates' categorical refusal to commit injustice. So strong is that conviction that Socrates disobeys despite the reasonably foreseeable wrath of the Tyrants (Apology 32d-e, 'I might have been put to death for it'). It is plausible to conclude, then, that on at least some occasions the imperative to not commit injustice trumps the duty to obey even a legitimate order.

A passage earlier in the Apology is even more telling. Echoing the deferential position detected in Crito (Crito 51a), Socrates remarks that 'it is wicked and shameful to do wrong, to disobey one's superior, be that god or man' (Apology 29b). This sweeping statement apparently leaves little room for disobedience, lest one be branded shameful and disgraceful. Yet almost immediately, Socrates imagines a scenario that sets limits to obedience:

If you said to me in this regard: "Socrates . . . we acquit you but only on condition that you spend no more time on this investigation and do not practice philosophy, and if you are caught doing this, you will die.' If, as I say, you were to acquit me on those terms, I would say to you, "Men of Athens, I am grateful and I am your friend, but I will obey the god, rather than you, and as long as I draw breath and am able, I shall not cease to practice philosophy."(Apology 29d)

Socrates would readily disobey a democratic jury's instruction to quit philosophising. His duty to god calls, on the one hand, for his constant philosophising; questioning others, he explains, is in 'service to the god' (Apology 22a). Justice demands that Socrates fulfils his divine duty and he continues investigating fellow citizens - a practice conducive to the common good (Apology 22a, 23b, 30a. On how the reference to god is truly about justice, see Apology 38a). On the other hand, he must abide by a court's legitimate order. The two commitments can pull, however, in opposite directions. Socrates' commitment to justice and philosophy prevails over his duty to abide by the jury's decision, weighty as the latter may be (Brickhouse and Smith 2004: 122-123, 131). Both examples discussed thus far indicate circumstances where Socrates' duty to obey law is overridden by some greater imperative. Disobedience is warranted because of the grave injustice obedience entails.

Socrates' resistance to a proscription of philosophising has typically been read as an example of a divinely ordained task that Socrates must follow irrespective of what the laws demand (see e.g. Howenstein 2009: 59. On the seriousness of elenchus and the imperative to pursue it even in light of legal authority, see Vlastos 1991: 134-135). But it also reveals, I argue, a ground for disobedience that does not rely on divine authority. It refutes, therefore, the erroneous suggestion that the Apology demands obedience to the state unless god commands one otherwise (Murphy 1979: 41). Philosophising entails for Socrates not merely, or even primarily, subjective cogitation, but above all freedom of expression and participation in the public sphere. Logos, translating reason and understanding, is also the Greek word for speech. Far from a product of solitary contemplation, reason is only realised through citizen interaction. Speaking to others is inextricably linked to rational thinking and is inarguably vital for attempts at persuasion. Philosophy is a manifestly communicative activity that requires dialogue with fellow citizens about issues of public concern. It is, therefore, Socrates' avowedly 
unconventional yet unquestionably powerful means of participation in Athenian democracy, given his legendary influence in his own time (Apology 31d). Rather than engage directly in law-making and attempt persuasion through formal channels, Socrates criticises, questions, and contests received democratic wisdom. Had a decision, even one resulting from established procedures, taken away Socrates' freedom to practise philosophy, it would essentially strip him of his democratic citizenship. Socrates would disobey not because a law takes away his preferred pastime, but because it deprives him of his citizenship; without philosophy, Socrates is no longer a citizen.

For Heinze, outlawing philosophy equals Socrates' disenfranchisement from democracy (cf. Brickhouse and Smith 2004: 232). Philosophy's legitimating function, he argues, rests on it being an instance of expression within public discourse (Heinze 2018: 126). Philosophy is a quintessentially political activity that adduces Socrates' position as a self-governing member of the Athenian democracy. If Athens gains legitimacy by allowing citizens to govern themselves and be politically active in democratic proceedings, then Socrates' exclusion from citizenship delegitimises, pro tanto, the Athenian regime. Far from resting on an abstract, quasi-religious duty to philosophise, Socrates' lawbreaking would be justified, in that case, on the basis of the absolute illegitimacy of a decision to exclude someone from self-government.

\subsection{Anticipating the Democratic Turn of Civil Disobedience}

The examples discussed in the preceding section reveal that Socrates' duty to obey is by no means absolute. Moreover, they contribute to our understanding of civil disobedience by revealing circumstances under which citizens are justified to disobey. With reference to those examples, I sketch two sets of circumstances under which disobedience becomes justified. The first refers to the substantive failures of a legitimate law, and the second is associated with failures of legitimacy. Liberal theories of civil disobedience, I suggest, tend to focus on cases falling in the first category. But democratic theories of civil disobedience, which have gained prominence in recent years, can better explain all examples found in Plato's writings.

To begin, a procedurally legitimate directive may command citizens to commit some egregious injustice. Again, Socrates' refusal to turn in Leon is justified in light of the sheer injustice resulting from compliance. In such cases, whatever duty to obey citizens normally incur must be breached to the extent of that injustice. ${ }^{27}$ These circumstances have been traditionally associated with conscientious objection. But there is no reason to exclude civil disobedience as a response to similar scenarios. It remains possible for citizens instructed to commit injustice to frame their actions as civil disobedience by emphasising the relevant communicative component (Ceva 2015). Performing civil disobedience, some draftees objecting to the injustice of the Vietnam War publicly burnt their draft notices. What is important for present

\footnotetext{
${ }_{27}$ For natural law theories that associate a law's legitimacy and its ability to command obedience with its substantive content, unjust laws fail to create moral duties of obedience entirely (See e.g., Aquinas and Thomas 2002). But this position is incompatible with the picture of legitimacy I have sketched throughout this article. Crito, I believe, supports the view that even unjust decisions reserve some legitimacy and can therefore lay a claim to one's obedience to the extent that they emanate from appropriate democratic processes.
} 
purposes is that this ground is sufficient for justified civil disobedience. Whether dissidents prefer one mode of protest to another depends on the particular historical, social, and political context.

If the demands of justice can plausibly justify lawbreaking, then why does Socrates choose obedience? Does a commitment to justice compel Socrates' disobedience? For Crito, this is surely the case. It is unjust, Crito contends, to let your enemies harm you (Crito 45c, 46a). ${ }^{28}$ And although Socrates does not directly address that claim in Crito, previous remarks in the Apology suggest that he does not consider the death sentence to be a great harm-even if his accusers certainly pursued it as such (Apology 30d. Socrates' metaphysical convictions about death prevent him from seeing it as an evil, see Apology 29a, 37b, 40b-41c). Socrates asserts that shunning one's duty in order to guard one's life is disgraceful (Apology 28b-d). ${ }^{29}$ For him to disregard the democratic laws by which he has lived, and which he has cherished perhaps more so than any other Athenian would be unfair and disingenuous (Crito 52a-b ('we [the Laws] and the city were congenial to you'). See also Vlastos 1991: 134). Fear of death cannot make Socrates abandon his quest of testing and investigating others. Nor can it make him betray the democratic principles by which he has conducted himself. There is injustice involved in Socrates' death sentence. But that injustice is not associated with Socrates' death per se. It is rather located in the mistaken democratic decision to convict an innocent person. In Socrates' eyes, we might presume, a conviction requiring him to pay a nominal sum would be equally unjust. In his plea at the sentencing stage, the philosopher announces that what he deserves is that he be bestowed appropriate honours for his service to the polis (Apology 36bd). Any form of penalty is undeserved and thus necessarily 'evil' and unjust. This explains why even though the conviction meant his death, what we would ordinarily recognise as the ultimate injustice, Socrates does not consider it adequate ground to derogate from his duty to obey. Suffering the conviction is therefore more preferable than committing the injustice of escaping a democratic decision, especially in light of Socrates' avowed belief that it is more objectionable to commit injustice than to suffer it (Crito 49c-d. Cf. Phaedo 61c-62b and Laws 873c-d. See Howenstein 2009: 61-62).

Academic literature since the end of World War II has largely accepted that legitimate instructions may be permissively disobeyed when they command egregiously unjust conduct. Liberal theories of civil disobedience face little difficulty justifying civil disobedience with reference to a law's substantive injustice. For Rawls (1999: 326), civil disobedience is justified when 'substantial and clear injustice' occurs. This commonly entails some profound violation of citizens' basic liberties. Only laws seriously infringing the basic liberties principle and blatantly violating the fair equality of opportunity principle are unjust enough to justify lawbreaking (Rawls 1999: 326-327). For Ronald Dworkin (1986: 107), in a similar vein, disobedience is justified when a majority acts in violation of the rights of others. It comes as no

\footnotetext{
${ }^{28}$ In Republic $1.335 \mathrm{~b}-\mathrm{e}$, Polemarchus propounds a similar view of what justice entails (justice requires action to benefit friends and harm enemies).

29 Socrates repeatedly remarks that he cares little for his own death, especially given his old age, Apology, 32c-d.
} 
surprise then that Socrates' position, permitting disobedience in cases when obedience would result in egregious injustice, is generally accepted by contemporary theories of political obligation and civil disobedience.

A second possible occasion for disobedience occurs when a procedurally legitimate directive entails violation of the regime's legitimating conditions. When a procedurally legitimate decision results in diminished opportunities for political engagement for groups or agents, disobedience becomes an appropriate response. Socrates' refusal to abide by a lawful proscription of philosophy would fall under this category. Even if the directive in question produces no severe substantive injustice (or at least not so extensive injustice that would be sufficient to justify derogation from a general duty to obey), lawbreaking remains justified because the directive's content would entail Socrates' exclusion from civic engagement.

A shortcoming of liberal models of civil disobedience is that in the absence of severe and conspicuous injustice, civil disobedience remains more difficult to justify. Such theories likely fall short of allowing disobedience for the second set of circumstances, unless they clearly raise questions of rights-violations. In permitting disobedience for cases in which a regime acts to diminish opportunities for political engagement, and thus acts to reduce its own legitimacy, Plato anticipates the democratic turn of contemporary civil disobedience discourse. For Plato, disobedience in those cases need not necessarily be justified with reference to the substantive injustice produced by the law, or the extent of that injustice. It is justified simply by the fact that the law compromises citizens' opportunities to be politically active. Contemporary democratic theories of civil disobedience seek to shift emphasis to such democratic deficits that justify lawbreaking (Habermas 1985; Celikates 2016; Smith 2013; Markovits 2005). Against the liberal paradigm that limits disobedience to cases of clear and egregious infringements of justice, democratic theorists of civil disobedience maintain that dissidents are morally justified to disobey when agents or discourses are excluded from or marginalised in political processes. When civic engagement is curtailed, resistance is an appropriate response (Celikates 2016: 992; Lefkowitz 2007). Theories of civil disobedience must permit lawbreaking when laws or policies obstruct opportunities of civic engagement, even when these directives are procedurally legitimate and do not explicitly raise questions of profound rights-violations.

Consider, for example, procedurally legitimate efforts to repress the political power of some groups through gerrymandering or other voter suppression laws. Gerrymandering is objectionable to the extent that it blunts the political control individuals or groups can exercise through elections (Weinstock 2016: 715). Such tactics typically secure formal protections of basic rights but substantively cut effective access to politics for parts of the population. The jury's decision to proscribe philosophy for Socrates resembles the gerrymandering scenario insofar as they both portray instances in which a legitimate decision seeks to strip citizens of some fundamental characteristic of citizenship (in the first case, participating in political discussions in the agora, and in the second voting). Given how liberal theories of civil disobedience have traditionally sought to restrict disobedience to cases of clear and profound violation of basic rights, excluding 'policy questions' or cases of procedural shortcomings that do not entail blatant rights-violations, it seems unlikely that 
they would permit civil disobedience in the gerrymandering scenario. Democratic theories of civil disobedience, which stress moral justifications for lawbreaking to address the regime's failures of legitimacy, are better suited to accommodate the gerrymandering scenario.

I do not suggest that liberal theories are always unable to recognise civil disobedience targeting democratic failures. They might be able to do so by linking the procedural failure in question to some substantive violation of basic rights. Yet this indirect approach remains insufficient; violations of basic rights are not always obvious. The inability to justify resistance when individual rights are afforded formal protection but are not, in practice, fully realised, means that the liberal model cannot, in the end, accommodate all the circumstances of resistance the democratic model purports to cover.

\section{Conclusion}

This article explores the existence and limits of a general duty on citizens to obey with reference to Plato's Crito and the Apology. The democratic claim, encapsulated in the slogan 'persuade or obey', ultimately grounds citizens' general commitment to law. As long as legal systems provide for opportunities for civic engagement and persuasion, they remain legitimate. Being sensitive to the differences between the Athenian democratic system and contemporary democracies, I have suggested that we can extrapolate from Crito legitimating criteria that influence the way we view current political systems. Plato's work can therefore illuminate the normative position of modern citizens vis-à-vis their legal systems. It can also help us conceptualise civil disobedience as a mechanism for attempting political persuasion.

Crito is frequently associated with an absolute duty to obey but I have shown that this position is incorrect. Far from supporting uncritical submission to authority, Crito and the Apology invite rigorous testing of a citizen's commitment to a broadly legitimate regime. I have therefore identified two sets of circumstances found in Plato's texts under which disobedience would be permissible within a broadly legitimate regime. First, legitimate laws may engender egregiously unjust outcomes. Second, legitimate laws may obstruct the exercise of democratic citizenship, thus contravening the conditions that render a political system legitimate in the first place.

Liberal models of civil disobedience are unable to accommodate fully both sets of circumstances. Focusing almost exclusively on disobedience as a challenge to the substantive injustice produced by legitimate laws, they neglect disobedience targeting violations of a regime's legitimating conditions. Democratic theories of civil disobedience, by contrast, stress the permissibility of civil disobedience as a response to decisions that diminish or hinder citizens' access to political participation. Such exclusion or marginalisation is frequently subtle and as such may fail to trigger models of civil disobedience focusing on substantive injustice. By permitting disobedience to attempts to diminish one's access to political participation, Plato anticipates the democratic turn of democratic discourses of civil disobedience. 
Acknowledgements I am indebted to Eric Heinze, Tom Hannant, and Aart Van Gils, and two anonymous referees for their valuable comments. Earlier versions of this paper were presented at the MANCEPT Workshop on 'Legitimate Injustice and Just Resistance', at University of Manchester, September 2018 and the POLEMO Symposium 2018 at the Central European University in Budapest. I thank all participants for their comments.

Open Access This article is licensed under a Creative Commons Attribution 4.0 International License, which permits use, sharing, adaptation, distribution and reproduction in any medium or format, as long as you give appropriate credit to the original author(s) and the source, provide a link to the Creative Commons licence, and indicate if changes were made. The images or other third party material in this article are included in the article's Creative Commons licence, unless indicated otherwise in a credit line to the material. If material is not included in the article's Creative Commons licence and your intended use is not permitted by statutory regulation or exceeds the permitted use, you will need to obtain permission directly from the copyright holder. To view a copy of this licence, visit http://creativecommons.org/licen ses/by/4.0/.

\section{References}

Aquinas, St. Thomas. 2002. Aquinas: Political Writings. Ed. Dyson R.W. 7th Edition. Cambridge: Cambridge University Press.

Arendt, Hannah. 1972. Crises of the Republic: Lying in Politics, Civil Disobedience, On Violence, Thoughts on Politics, and Revolution. New York: Penguin.

Arendt, Hannah. 1998. The Human Condition. Chicago: University of Chicago Press.

Aristotle, S. 1998. Politics. Indiana: Hackett Publishing.

Aristotle, 1999. Nicomachean Ethics. Indianapolis: Hackett Publishing.

Bedau, Hugo (ed.). 1991. Civil Disobedience in Focus. London: Routledge.

Brickhouse, Thomas, and Nicholas Smith. 2004. Routledge philosophy guidebook to Plato and the trial of Socrates. New York: Routledge.

Brown, Vivienne. 2001. Self-Government: The Master Trope of Republicanism. The Monist. 84(1): 60-76.

Brownlee, Kimberley. 2012. Conscience and Conviction: The Case of Civil Disobedience. Oxford: Oxford University Press.

Celikates, Robin. 2016. Democratizing Civil Disobedience. Philosophy and Social Criticism. 42(10): 982-994.

Ceva, Emanuella. 2015. Political Justification through Democratic Participation: The Case for Conscientious Objection. Social Theory and Practice 41(1): 26-50.

Cooper, John (ed.). 1997. Plato: Complete Works. Indianapolis/Cambridge: Hackett Publishing Company.

Dagger, Richard and Lefkowitz, David. 2014. Political Obligation. The Stanford Encyclopedia of Philosophy. Retrieved from https://plato.stanford.edu/archives/fall2014/entries/political-obligation/. Accessed 14 Nov 2018.

Delmas, Candice. 2017. Disobedience, Civil and Otherwise. Criminal Law and Philosophy 11(1): 195-211.

Douzinas, Costas. 2013. Philosophy and Resistance in the Crisis: Greece and the Future of Europe. Cambridge: Polity Press.

Dworkin, Ronald. 1986. A Matter of Principle. Oxford: Clarendon Press.

Dworkin, Ronald. 1998. Law's Empire. Oxford: Hart Publishing.

Finnis, John. 2011. Natural Law and Natural Rights. Oxford: Oxford University Press.

Gowder, Paul. 2015. What the Laws Demand of Socrates—and of Us. The Monist 98: 360-374.

Habermas, Jurgen. 1985. Civil Disobedience: Litmus Test for the Democratic Constitutional State. Berkeley Journal of Sociology. 30: 95-116.

Habermas, Jürgen. 1996. Between Facts and Norms. Boston: MIT Press.

Hart, H. L. A. 1955. Are There Any Natural Rights? The Philosophical Review 64(2): 175.

Hart, H.L.A. 1982. Essays on Bentham: Studies in Jurisprudence and Political Theory. Oxford: Oxford University Press. 
Hart, H.L.A. 2012. The Concept of Law. Oxford: Oxford University Press.

Heinze, Eric. 2016. Hate Speech and Democratic Citizenship. Oxford: Oxford University Press.

Heinze, Eric. 2018. The Constitution of the Constitution. In Rancière and the Possibility of Law, ed. Etaxbe Julen. Lopez Lerma Monica. London: Routledge.

Herrera, C.D. 1995. Civil Disobedience and Plato's Crito. The Southern Journal of Philosophy. 33(1): 39-55.

Homiak, Marcia. 2002. Feminism and Aristotle's Rational Ideal. In Feminism and History of Philosophy, ed. Lloyd Genevieve. Oxford: Oxford University Press.

Howenstein, Mark. 2009. Socrates and the Moral Limits of Legal Obligation. Law, Culture and Humanities. 5: 55-76.

Hume, David. 1994. Of the Original Contract. In Hume: Political Essays, ed. Haakonssen Knud. Cambridge: Cambridge University Press.

Kahn, Charles. 1996. Plato and the Socratic Dialogue: The Philosophical Use of a Literary Form. Cambridge: Cambridge University Press.

King, Jr., Martin Luther. 1986. A Testament of Hope: The Essential Writings of Martin Luther King Jr. Ed. Washington, J.M. San Fransisco: Harper \& Row Publishers.

King Jr., Martin Luther. 1991. Letter from Birmingham City Jail. In Civil Disobedience in Focus, ed. Bedau Hugo. London: Routledge.

Kirkpatrick, Jennet. 2015. Exit out of Athens? Migration and Obligation in Plato's Crito. Political Theory 43(3): 355-379.

Kraut, Richard. 1984. Socrates and the State. Princeton: Princeton University Press.

Lefkowitz, David. 2007. On a Moral Right to Civil Disobedience. Ethics 117: 202-233.

John, Locke. 1980. Second Treatise on Government. Indianapolis: Hackett Publishing.

MacDowell, Douglas. 1978. The Law in Classical Athens. London: Thames and Hudson.

MacIntyre, Alasdair. 1994. A Partial Response to my Critics. In Horton, John, ed. After MacIntyre. Notre Dame, Ind: University of Notre Dame Press.

Markovits, Daniel. 2005. Democratic Disobedience. Yale Law Journal. 114: 1897-1952.

Murphy, J.G. 1979. Violence and the Socratic Theory of Legal Fidelity. Retribution, Justice, and Therapy 16: 40-57.

Nussbaum, Martha. 1990. Aristotelian Social Democracy. In Liberalism and the Good, ed. Douglass Bruce, Mara Gerald, and Richardson Henry. London: Routledge.

Ober, Josiah. 2002. Political dissent in democratic Athens: intellectual critics of popular rule, 3rd ed. Princeton: Princeton University Press.

Olsen, Frances. 1984. Socrates on Legal Obligation: Legitimation Theory and Civil Disobedience. Georgia Law Review. 18: 929-966.

Pettit, Philip. 1997. Republicanism. Oxford: Oxford University Press.

Pettit, Philip. 2012. On the People's Terms: A Republican Theory and Model of Democracy. Cambridge: Cambridge University Press.

Pitkin, Hanna. 1965. Obligation and Consent-I. The American Political Science Review. 59(4): 990-999.

Plamenatz, John. 1968. Consent, Freedom, and Political Obligation, 2nd ed. Oxford: Oxford University Press.

Rancière, Jacques. 2006. Hatred for Democracy. London: Vestro.

Rawls, John. 1964. 'Legal Obligation and the Duty of Fair Play' in Law and Philosophy Ed. Sidney Hook. New York: New York University Press.

Rawls, John. 1999. A Theory of Justice. Cambridge: Harvard University Press.

Raz, Joseph. 1979. The Authority of Law. Oxford: Clarendon Press.

Rosano, Michael. 2000. Citizenship and Socrates in Plato's 'Crito'. The Review of Politics. 62(3): 451-477.

Saffron, Maria Paula, and Nadia Urbinati. 2013. Procedural Democracy: The Bulwark of Equal Liberty. Political Theory 41(3): 441-481.

Simmons, John. 1979. Moral Principles and Political Obligations. Princeton NJ: Princeton University Press.

Smith, M.B.E. 1973. Is There a Prima Facie Obligation to Obey the Law? Yale Law Journal 82: 950-976.

Smith, William. 2013. Civil Disobedience and Deliberative Democracy. London: Routledge.

Taylor, A.E. 1927. Plato: the man and his work, 2nd ed. London: Methuen.

Todd, Stephen, and Millet Paul. 1990. Law, society, and Athens. In Nomos: Essays in Athenian Law, Introduction, ed. Cartledge Paul, Miller Paul, and Todd Stephen. Cambridge: Cambridge University Press. 
Vlastos, Gregory. 1991. Socrates, Ironist and Moral Philosopher. Ithaca: Cornell University Press.

Waldron, Jeremy. 2005. Virtue En Masse. In Debating Democracy's Discontent, ed. Anita Allen and Milton Regan. Oxford: Oxford University Press.

Walker, A.D.M. 1989. Obligations of Gratitude and Political Obligation. Philosophy and Public Affairs 18: 359-364.

Weinstock, Daniel. 2016. How Democratic is Civil Disobedience? Criminal Law and Philosophy. 10: $707-720$.

Weiss, Roslyn. 1997. Socrates Dissatisfied: An analysis of Plato's Crito. Oxford: Oxford University Press.

Woozley, A.D. 1979. Law and Obedience: the arguments of Plato's 'Crito'. London: Duckworth.

Young, Gary. 1974. Socrates and Obedience. Phronesis 19(1974): 1-29.

Zinn, Howard. 1991. Law, Justice, and Disobedience. Notre Dame Journal of Law, Ethics, \& Public Policy 5: 909-910.

Publisher's Note Springer Nature remains neutral with regard to jurisdictional claims in published maps and institutional affiliations. 